\title{
下北半島の大畑漁港〜尻屋崎間の 弓状海岸における海浜地形変化 \\ BEACH CHANGES AT EMBAYED COASTLINE BETWEEN OHATA FISHING PORT AND SHIRIYAZAKI POINT IN SHIMOKITA PENINSULA
}

\author{
宇多高明 ${ }^{1} \cdot$ 花田一之 ・石川仁憲 $^{3} \cdot$ 清野聡子 $^{4} \cdot$ 太田慶正 $^{5} \cdot$ 角本孝夫 $^{6}$ \\ Takaaki UDA, Kazuyuki HANADA, Toshinori ISHIKAWA, Satoquo SEINO, \\ Yoshimasa OHTA and Takao KAKUMOTO \\ ${ }^{1}$ 正会員 工博 国土交通省 土木研究所 河川部長（テ305-0804 茨城県つくば市旭1） \\ 2青森県むつ土木事務所 ( T035-0073青森県むつ市中央1-1-8) \\ ${ }^{3}$ 正会員 工修 パシフィックコンサルタンツ(株)( ₹206-0011東京都多摩区関戸1-7-5) \\ ${ }^{4}$ 正会員 農修 東京大学大学院総合文化研究科広域システム科学科(テ153-8902 東京都目黒区駒場3-8-1) \\ 5 青森県大畑町役場総務課（ $T 039-4495$ 青森県下北郡大畑町字中島） \\ 6 ‘94フォーラム in 大畑(代表者:角本孝夫 T039-4401青森県下北郡大畑町字上野96-8)
}

\begin{abstract}
Shoreline changes at the embayed coastline between Ohata fishing port and Shiriyazaki Point in Shimokita Peninsula were investigated by field observation and reading of aerial photographs. In this area, swells are incident from NE mainly in summer, whereas NW wind blows in winter causing rough wind waves. Since the shape of the coastline is semicircular and eastern half of the coastline is well protected by the peninsula itself against summer swells, predominant direction of littotal drift is eastward. Large shoreline recession with the formation of sea cliff was observed on the east side of harbor and detached breakwaters.
\end{abstract}

Key Words : Beach erosion, Shimokita, aerial photographs, sea cliff

\section{1. まえがき}

わが国沿岸域においては,産業の発展を目的とし て多くの港湾・漁港施設が造られてきている.これ らの施設の建設にあたっては一般に様々な形態の防 波堤が建設されるが,従来何も施設のなかった海域 においてこれらの施設が建設されると,影響の程度 は様々としても,波浪・漂砂の場に必ず変化が起こ る. そしてその影響は施設の形状と,その海岸の漂砂 条件によって様々に変化する。一方向の沿岸漂砂が 卓越した海岸で沿岸漂砂の移動が妨げられれば施設 の上手側では堆積が,下手側では侵食が生じるし,沖 合に波の遮蔽構造物が建設されれば波の遮蔽域内で は土砂が堆積し,周辺域では汀線が後退する11.この ようにして防波堤の建設による侵食影響が周辺域に 及ぶ場合,その影響の範囲と程度を時間的・空間的 に十分見極めておくことが必要である.従来なされ てきた災害復旧的な対応では投入費用に比較して十 分な効果が上がらないことが多いためである.本来 的には,各種施設の建設によってもたらされる便益 と,このような周辺環境の維持に要する費用を総合
的に検討した上で計画を立てる必要があるが,わが 国沿岸では既に多くの施設が建設されてきているの で,建設当初にまで遡って議論することは科学的に は可能ではあっても現実的ではないので,ここでは

「施設ありき」の条件下で,今後いかなる方式で海 岸保全を進めれば良いかについて青森県下北半島の 津軽海峡沿岸を例として考察する.

調查対象は下北半島の大畑漁港から尻屋崎まで延 長約 $30 \mathrm{~km}$ の海岸線である.この区域の漂砂について は過去に公表されたデータは存在しない.そこで現 地踏查計画を立てた. まず,2000年8月17日には大畑 漁港から尻屋崎まで,漁船に乗って海岸線を大局的 に観察し,問題箇所を抽出した後,大畑漁港から陸路 海岸線を南下し,典型的な海浜変形が見られた箇所 で詳細現地踏査を行った.あわせて1999年10月撮影 の空中写真（青森県撮影）を入手し, 現地海岸の状 況と比較検討した. 以下では, 浜関根港, 石持漁港お よび野牛漁港周辺での踏查結果について述べ,最後 にそれらを要約しこの沿岸における今後の海岸保全 のあり方について考察する. 


\section{2. 調查地域の概要}

調查地域は, 図-1に示すように青森県下北半島北 部の津軽海峡沿岸である.下北半島は斧の形状を有 するが, 調査区域は下北半島北部の津軽海峡に面し た大間崎から尻屋崎に至る延長 $57 \mathrm{~km}$ の海岸線のうち, 大畑町から尻屋崎まで延長約 $30 \mathrm{~km}$ の海岸線である. 大畑以北では海岸線のほとんどは岩礁で覆われてい るのに対し.大畑から東側には砂浜海岸と海食崖が 分布している.この区域には, 現在は廃船となった原 子力船「むつ」の母港であった浜関根港が立地する とともに, 沿岸にはいくつかの漁港がある.

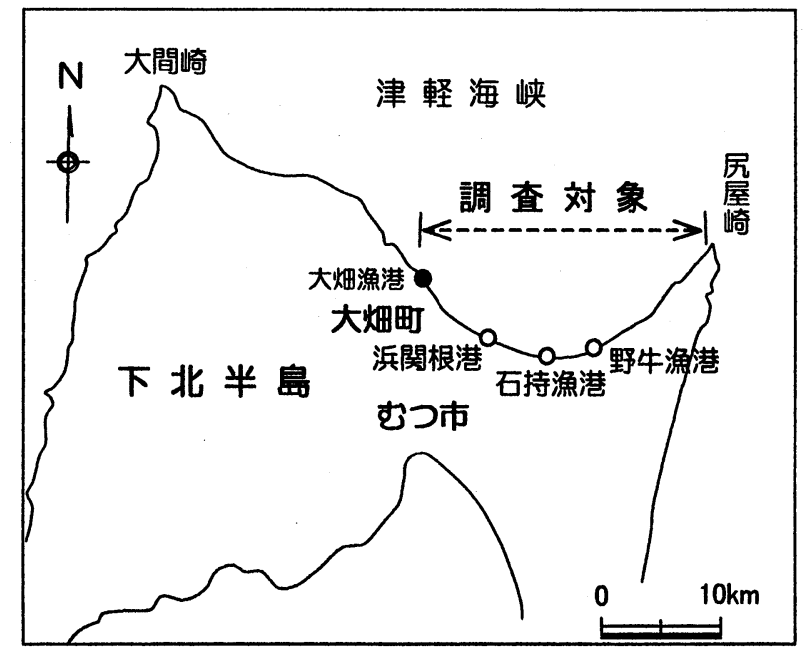

図-1 下北半禹の調査区域の位量

図-1に示したように対象海岸線はお椀状に湾入し, 尻屋崎が鋭く突出しているため, 太平洋からの入射
波浪は直接的に作用しにくい地形条件にある.大畑 から北海道日高沿岸までの対岸距離は約 $95 \mathrm{~km}$ である が, 尻屋崎と北海道の恵山岬の間が約 $32 \mathrm{~km}$ 開いてい るため, 太平洋からの入射波浪はほぼ東側から入射 する.この場合, 尻屋崎の西側隣接部は波の遮蔽域に 入る.一方, 冬季の季節風時には北西風が吹き, この 場合津軽海峡で発達した風浪の作用が凹状海岸線の 東部で著しくなる.

図-2は調査地域の拡大図であるが, 図には詳細調 査を行った浜関根港, 石持漁港および野牛漁港周辺 の空中写真の撮影範囲も示す.ここに, 石持漁港はお 椀状海岸線の底に位置し, 浜関根港はこの石持漁港 より西側に約 $4.7 \mathrm{~km}$, 野牛漁港は東側に約 $3.5 \mathrm{~km} に$ 位 置している.

\section{3. 空中写真と現地踏査に基づく侵食状況調査}

\section{（1）浜関根港の東側隣接区域}

浜関根港の東側隣接区域では, 防波堤の建設に伴 う波浪場の変化によって激しい侵食が生じている。 写其-1は1999年10月撮影の空中写真である. 浜関根 港には直線状の北防波堤, 「く」の字形の南防波堤, および沖防波堤が建設されている.また浜関根港の 北西側には隣接して関根漁港が立地している. 写真 に示すように, 浜関根港の東側約 $0.28 \mathrm{~km}$ には2基の離 岸堤 (西側をA, 東側をB離岸堤と呼ぶ) が設置されて いる. A, B離岸堤の堤長はそれぞれ36. $3 \mathrm{~m}, 110.1 \mathrm{~m}$ であ る.B離岸堤の端部から東側には約 $210 \mathrm{~m}$ の開口部があ り,さらにその東側には堤長が東向きに次第に短く なる離岸堤群が設置されている.この海域では冬季,

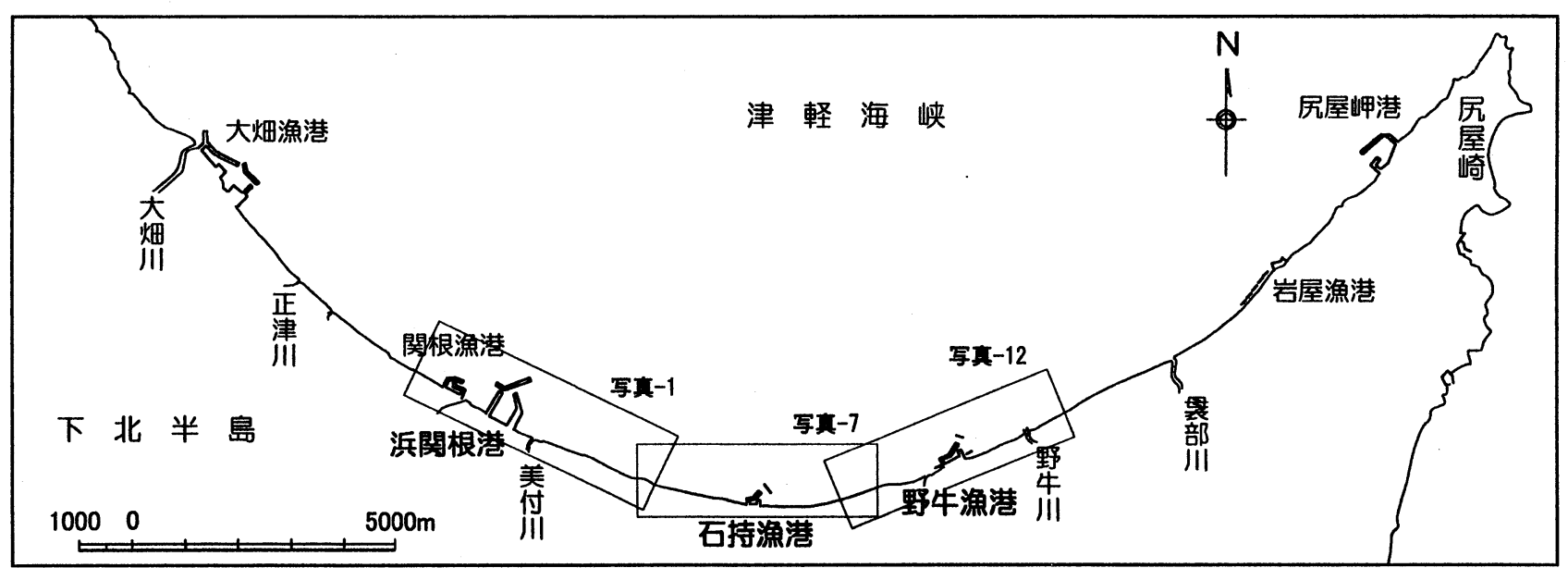

図-2 浜関根港, 石持漁港および野牛漁港の位置

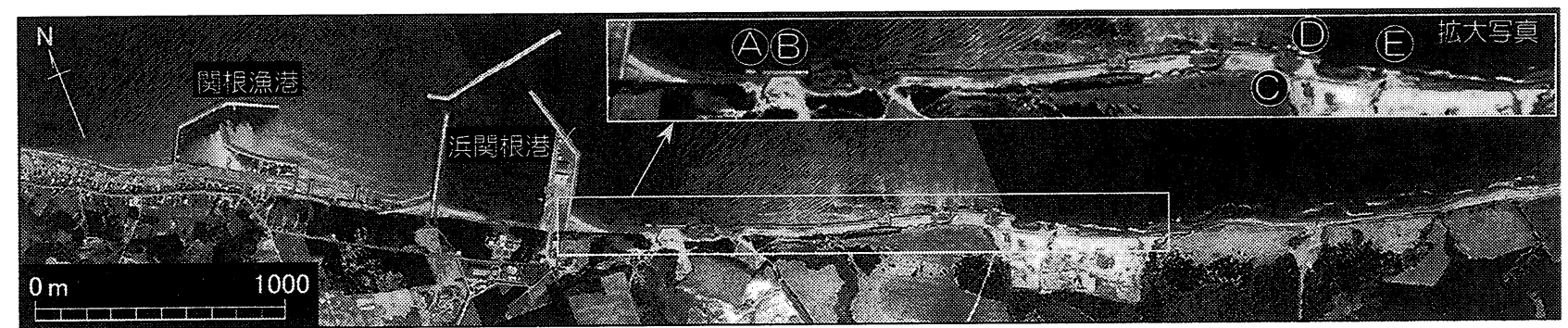

写真-1 浜関根港周辺の空中写真（1999年10月青森県撮影） 


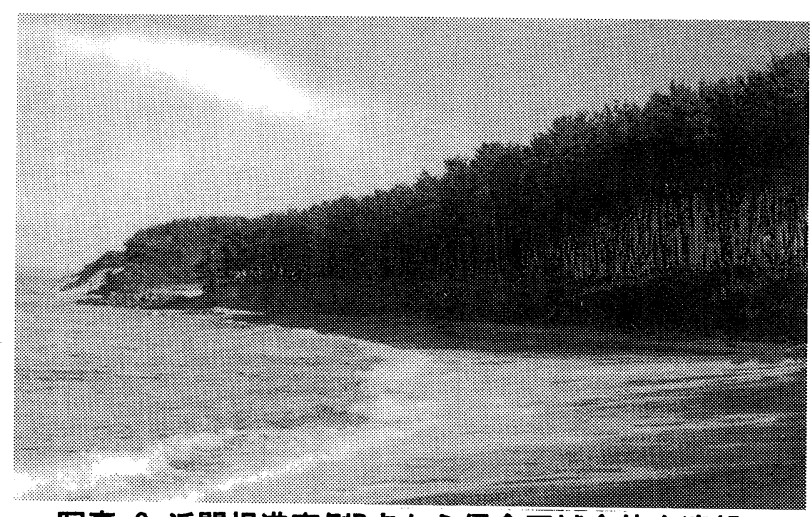

写真-2 浜関根港東側 $\mathrm{B}$ 点から僈食区域全体を遠望

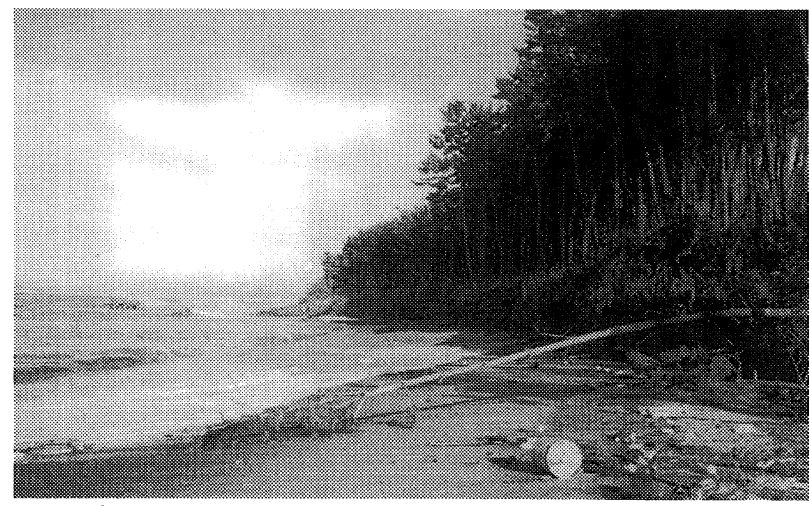

写真-3 侵食によって浜卦が形成された保安林区域

北西側からの波浪の入射が著しいが, この波浪が沖 防波堤により回折し. 浜関根港の東側区域に作用す る. とくに写真-1に示すB離岸堤の東側は開口幅が $200 \mathrm{~m}$ 程度と広いので防波堤からの反射・回折波が強 く作用するにとどまらず,離岸堤の存在自体によっ ても局所的に波高が高まるので,これらの施設がな かった時に比べて波浪の作用が著しい。このため離 岸堤の開口部では侵食が著しい.

写真-2は, B離岸堤背後のトンボロから東側の海岸 状況を撮影したものであるが, 海岸線が大きく後退 したことにより背後の保安林（松林）が欠け込んで いる. 写真-3は保安林の基部にさらに接近して撮影 したものであるが, 浜崖が松林の中まで入り込んで おり, 松の倒木も見られる.この松林の背後には道路 があるが侵食が進んだ結果, 道路と海岸線の間の松 林は非常に狭くなり，侵食を放置できない状態と なっている.

写真-1においてさらに東側の台地上のC点（写真1参照）から西側を撮影したのが写真 -4 である.この 付近から浜関根港方面を遠望すると, 狭い開口部を 有する離岸堤が直線状に延びている.この付近の海 岸線には海食崖が連なっており,それに平行に離岸 堤が設置されている. 写真- 5 は, 同じくC点 (写真-1 参照）から東側を撮影したものである.この付近で は土砂採取が行われたために地表面は剥き出しの裸 地となっている. 写真-5左端の離岸堤位置を写真-1 にDで示すが,離岸堤Dの東側開口幅は約 $100 \mathrm{~m}$ と広い ので,そこからの波浪侵入が著しく, 背後地が大きく 削り取られている.

写真-6はこの裸地の東端近傍にある離岸堤 $\mathrm{E}$ (写

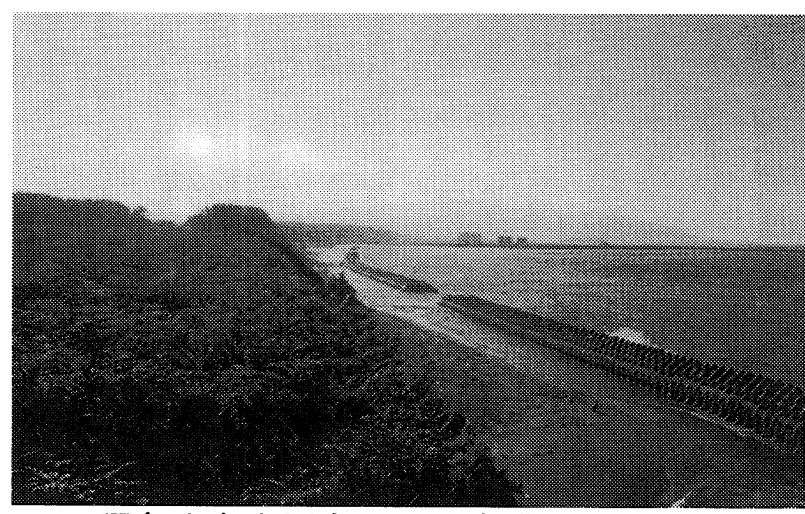

写其-4 台地上C点から浜関根港方面を遠望

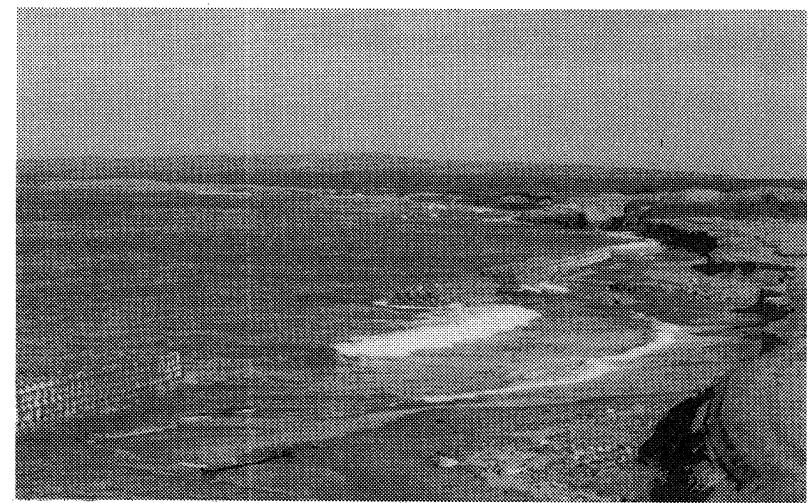

写真-5 台地上C点から東側の侵食域を望む

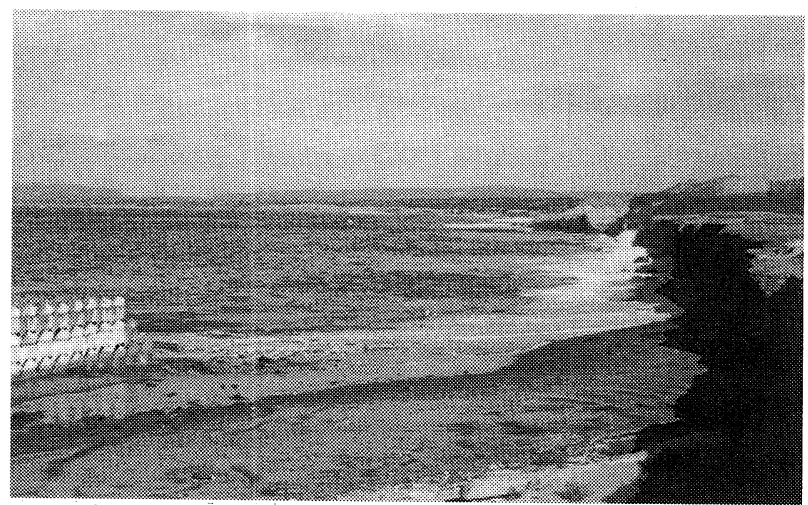

写真-6 裸地の東端近傍の離岸堤とその東側の浜崖

真-1参照）とその東側の裸地の関係を示す.この付 近には離岸堤などの消波構造物がないので浜崖を形 成しつつ激しく侵食が進んでいることが分かる.

以上のように, 浜関根港の東側区域では海岸線に 沿って多くの離岸堤が設置されており,その未設置 区間では侵食が進み浜崖の形成が著しい，また, 写 真-1に示したように, 浜関根港の西側には関根漁港 が位置し,この西側と浜関根港東側の海岸線形状を 比較すると, 一方向に卓越する沿岸漂砂のある海岸 において見られるような状況（どちらかの海岸では 汀線が大きく前進し, 逆側は大きく後退する. ) には ない.しかし, 関根漁港の西側には海浜地があるのに 対して, 浜関根港の東側では海食崖がむき出しと なっていることを考慮すると, 全体的にやや東向き の沿岸漂砂が卓越し, それに防波堤による波の遮蔽 域形成に伴う防波堤基部での汀線前進が重なってい ると推定される.これより浜関根港の東側区域では 今後侵食がさらに激化する方向にあると考えられる. 


\section{（2）石持漁港周辺海岸}

写真-7は石持漁港周辺の空中写真を示す.この写 真は写真-1に示した空中写真の東側の連続空中写真 である. 写真に示すように長く海食崖の続く海岸線 に石持漁港の防波堤が延びている.防波堤を挟んで 西側では前浜が広く,一方東側では防波堤の基部に は三角形状の前浜が存在するが, 東防波堤から約 $240 \mathrm{~m}$ 離れた点 $\mathrm{A}$ から $320 \mathrm{~m}$ 離れた点 $\mathrm{B}$ までの間には前浜 が全く存在せず, 海食崖が剥き出しになっている.し かし点 $\mathrm{B}$ から東側では再び前浜が広がっている.石 持漁港ではこの付近の平均海岸線と約 $115^{\circ}$ と大き な角度をなして沖防波堤が建設されているが，この 防波堤に対して北東方向から入射寸る太平洋からの 波浪が反射することによって漁港の東側隣接部で波 向・波高場が変化した結果, 写真に示す汀線状況に なったと考えられる.

写真-8は石持漁港の西側に延びる旧海食崖の中腹 から西側を望んで撮影したものである.この付近で は石持漁港の防波堤の建設以前には海食崖が続いて いたが, 漁港防波堤の建設によって海食崖の前面に 東向きの沿岸漂砂が堆積し,前浜が大きく広がった。
写真-7より, 石持漁港から汐崎までの旧海食崖を連 ねる線から台形状に広がった前浜の最大前進距離は 約 $100 \mathrm{~m}$, 最小前進距離は約 $50 \mathrm{~m}$, 堆積区域の広がり幅 は約650mに達するので, 堆積して形成された前浜の 面積は約 $49,000 \mathrm{~m}^{2}$ となる. また写真-8に示したよう に, 堆積して形成された前浜の大部分には植生が進 出しているが, このことはこの海浜が安定している ことを示しており堆積域ではバームが形成され安定 した海浜であることがよく分かる.

写真-9は旧海食崖の中腹から石持漁港の防波堤を 望んだものであるが, 防波堤の西側には防波堤に よって東向きの移動を妨げられた土砂が多く堆積し て広い前浜が形成されたこと,そして陸側から安定 な海浜地へと植生帯が広がりつつある状況が見て取 れる.

以上の石持漁港西側の海浜状況と比較して, 東側 では著しく侵食された状況が見て取れる.写真-10は 東防波堤の中央部から東側の海岸状況を撮影したも のである. 写真手前側には三角形状の前浜が広がっ ているが,この前浜は沖防波堤および東防波堤によ る波の遮蔽域において東防波堤に隣接して形成され

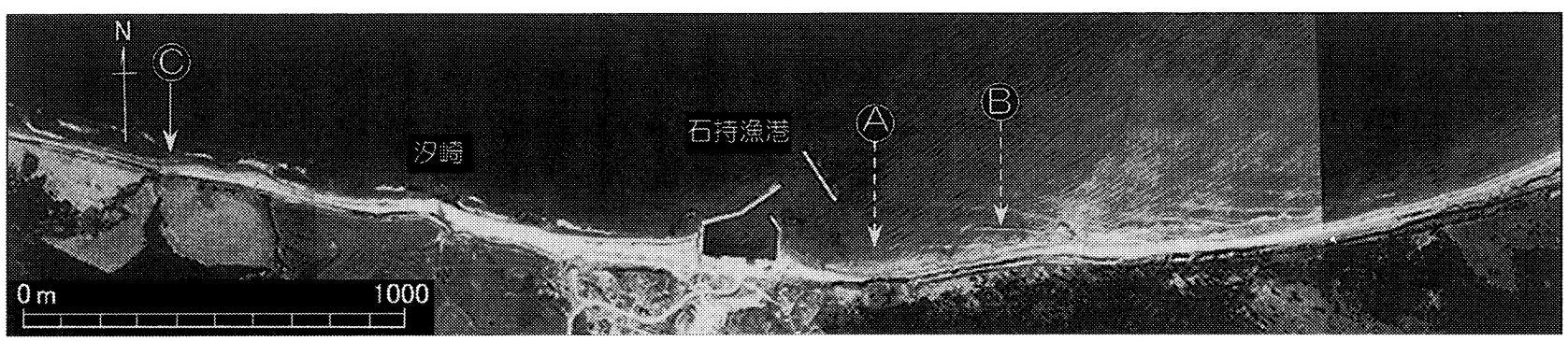

写真-7 石持漁港周辺の空中写真（1999年10月青森県撮影）

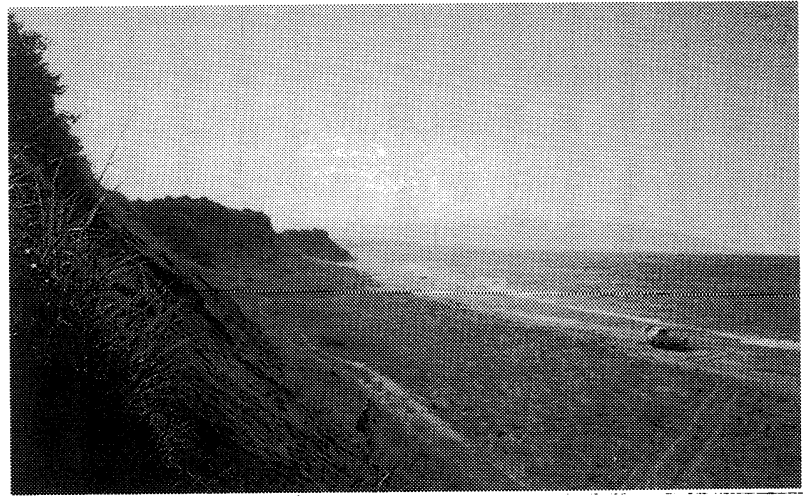

写真-8 石持漁港西側の旧海食崖から西側を望む

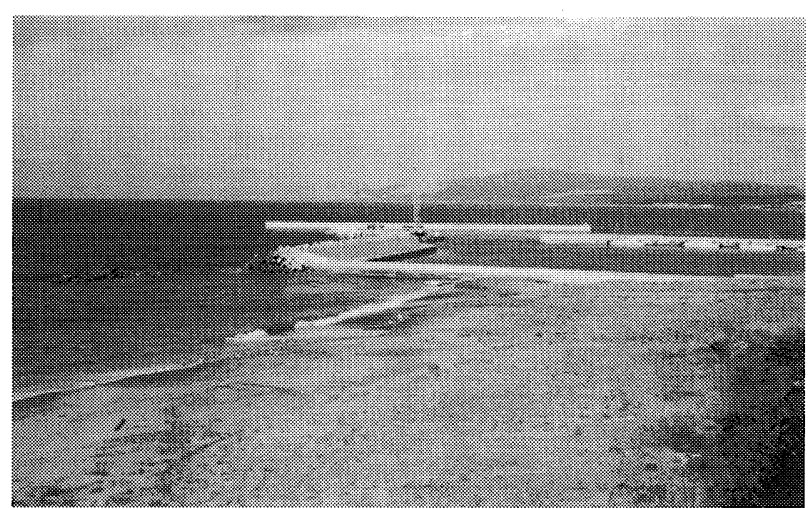

写真-9 石持漁港西側の旧海食崖から東側を望む

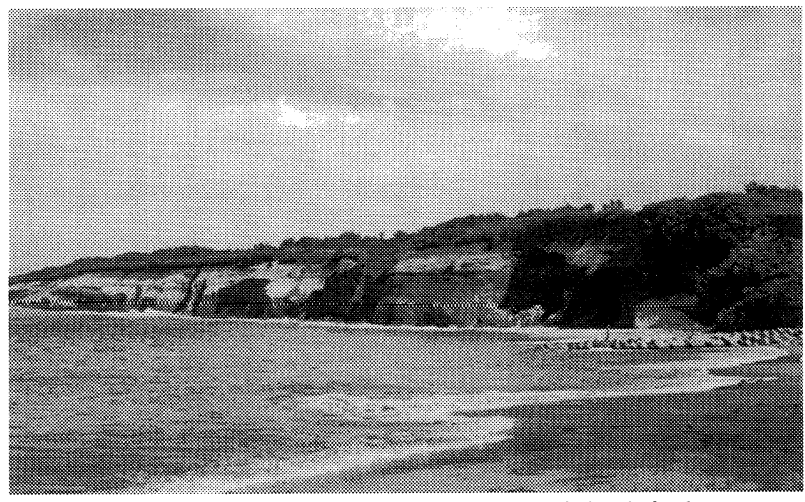

写真-10 石持漁港東防波堤から東側を望む

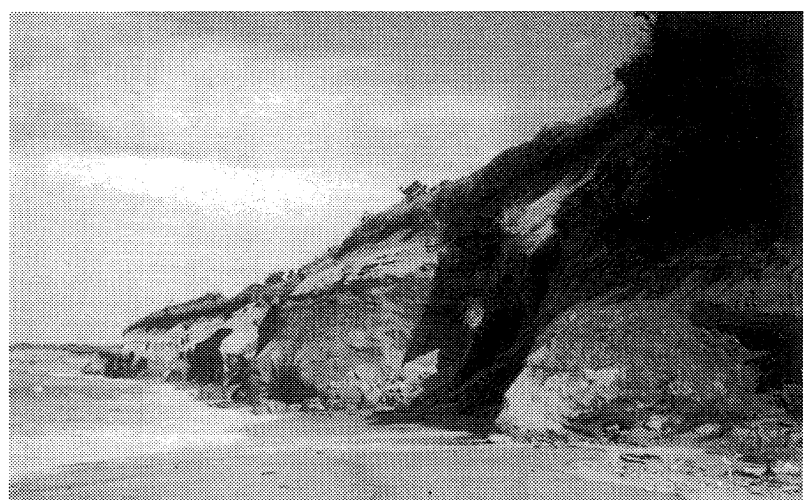

写真-11 石持漁港東側の海食崖の状況 
た三角形状の前浜の一部である.それより遠方には 連続した高い海食崖が見られる.この崖が写真-7に 示したように沖防波堤からの反射波によって形成が 進んだ海食崖である. 写真-10の右端付近に接近して 海食崖の近傍から撮影したのが写真-11である.未固 結の海食崖で崩落が進んでいる. 国土地理院の地形 図によれば海食崖の高さは約25mに達する.

\section{（3）野牛漁港の周辺海岸}

写真-12 は野牛漁港周辺の空中写真である.この写 真は写真-7に示した石持漁港周辺の空中写真の東側 にそのままつながるものである.海岸線に対してや や斜めに延ばされた防波堤があり,その両側には離 岸堤が設置されている.それぞれの離岸堤の背後に は土砂が堆積してトンボロが形成されている.一方, 野牛漁港の防波堤から東に約 $0.7 \mathrm{~km} \sim 0.86 \mathrm{~km}$, 西に 約 $0.3 \mathrm{~km} \sim 0.56 \mathrm{~km}$ 離れた場所には緩傾斜護岸が設置 されている.

野牛漁港の北東側の, 写真-12に点Aで示す位置の 緩傾斜護岸を撮影したのが写真-13である.この付近 では緩傾斜護岸の前面に前浜は全く存在せず,護岸 前面は波に晒されている.しかし護岸の東側端部で は写真-14に示すように護岸端部で汀線が後退し, 浜

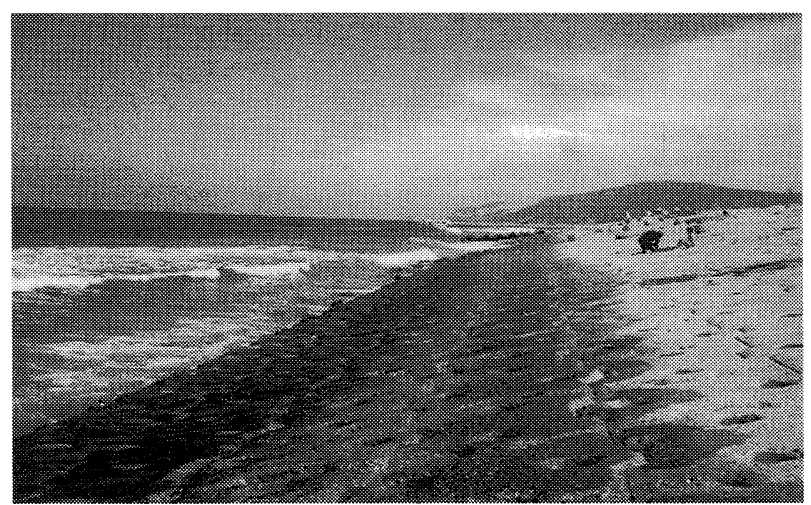

写真-13 野牛漁港北東側の緩傾斜護岸

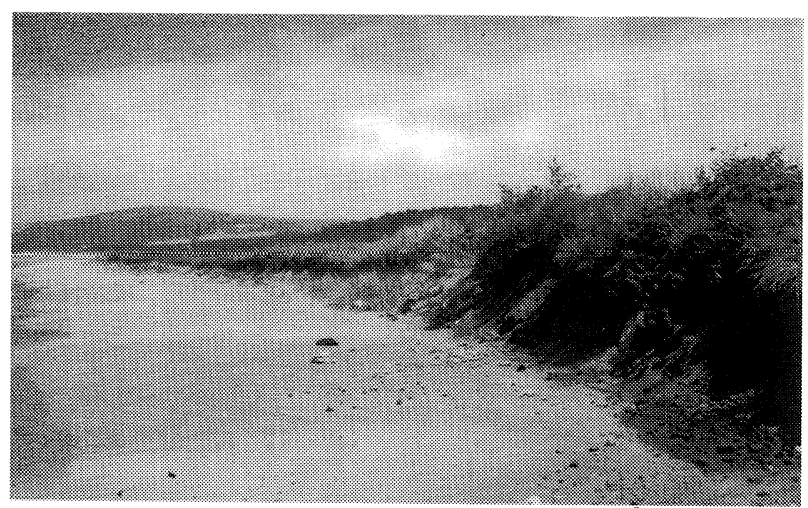

写真-14 緩傾斜護岸北東側端部の浜崖の形成状況
崖の形成が進んでいる. 浜崖の高さは護岸端部近傍 で高さ約 $2 \mathrm{~m}$ と最も高く, 北東側ほど高さが低くなる. このことは, 汀線の後退とそれに伴う浜崖の形成が 東向きの沿岸漂砂によって生じたことを意味する. しかし野牛漁港の西約 $0.3 \mathrm{~km}$ にある緩傾斜護岸の西 側端部も以上と同様な端部での汀線の後退が見られ, さらに野牛漁港の東約 $1.3 \mathrm{~km}$ に位置する野牛川の河 口導流堤では両側の汀線がほぼ対称形を有している. このことは, 野牛漁港周辺では東向きと西向きの沿 岸漂砂が存在するものの, 両方向のエネルギーフ ラックスがほぼ均衡していることを意味する.

野牛漁港の西約 $1.3 \mathrm{~km}$ の部は稲崎である.ここに は岬沖に岩礁があるためへッドランド状になってい る.稲崎の西側には海食崖が続いている.

\section{4. 漂砂機構と今後の方策について}

\section{(1) 漂砂機構}

前節の結果を系統的に整理すると，まず浜関根港 周辺では港の東側地区の侵食が西側地区と比較して 相対的に著しいことから, やや東向きの沿岸漂砂が 卓越する場において波の遮蔽構造物の建設に伴う地 形変化が重なっていると判断される.

石持漁港周辺では漁港を挟んだ東西での海浜状況 の著しい相違から, 東向きの沿岸漂砂が著しく卓越 している.これに加えて, 石持漁港の東側では斜め沖 防波堤によって反射波が生じ,これに起因して汀線 が凹状になりつつあると推定できる. 波がほぼ直角 入射する海岸であれば, 斜め沖防波堤建設に伴う汀 線後退はある程度進めば終息しうるが, 石持漁港の 場合には海食崖の崩落土砂は東向きに移動してしま うために, 海食崖の後退に伴う海食崖の安定化は進 みにくいと考えられる.

野牛漁港周辺では一方向の沿岸漂砂は卓越してい ないが, 波の遮蔽構造物に周辺から砂が集められた 結果, 漁港周辺域では海浜が狭くなってきている.

以上の海浜変形のうち, 防波堤設置に伴う局所的 汀線変化を除いた大局的な漂砂の機構は図-3の模式 図に要約される.お椀状の海岸線に対し,その中心線 方向から波が入射する場合には図-3(a)のように両 端部で汀線が後退し中央部では汀線が前進する. し かし本研究の対象地区での海浜変形は明らかにこれ と異なる.図-3(b) のように, お椀状の湾入海岸線に 対し時計回りの方向から波が入射すると, 尻屋崎の 西側隣接区域では岬の遮蔽効果によって波浪は静稳 であるが, 大畑側では波高が高まる.しかし大畑側で は海岸線の方向が波の入射方向とほぼ直角なので著 しい沿岸漂砂は生じない. しかし湾入部の底付近で

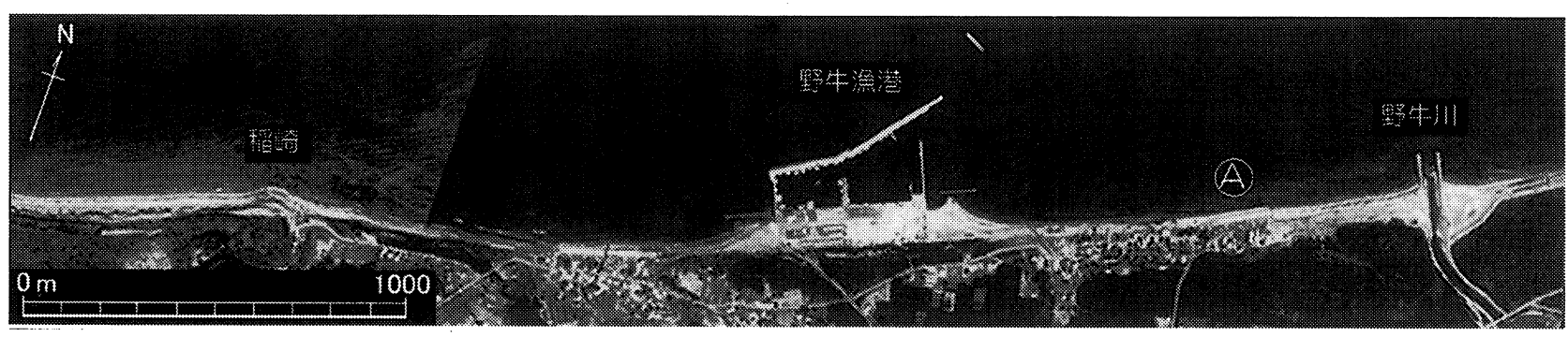

写真-12 野牛漁港周辺の空中写真（1999年10月青森県撮影） 
は波の入射方向とのなす角が大きいために,西向き の沿岸漂砂が生じる. 冬季にNW方向の風が吹く場合 は図-3(c)のようにこれと逆となる. 時計回り,反時 計回りの波浪の作用が季節的に重なり,かつNW方向 からの波浪の作用が太平洋側からの波浪作用より強 い場合, 図-3(d)に示すようにnet（正味）の沿岸漂 砂の方向は東向きとなる.

(a) 直角入射

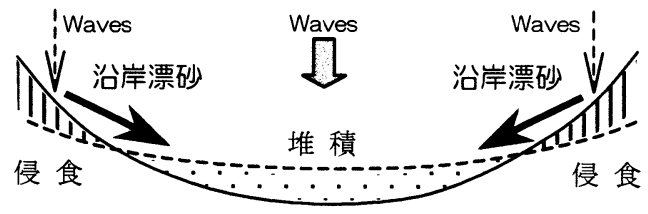

(b) 時計回りより入射

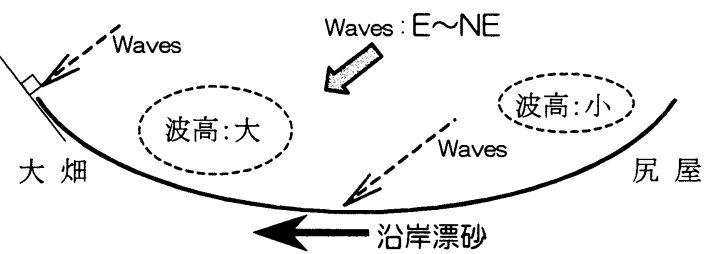

(c) 反時計回りより入射

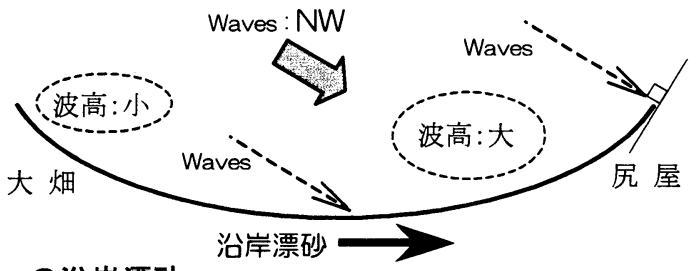

(d) netの沿岸漂砂

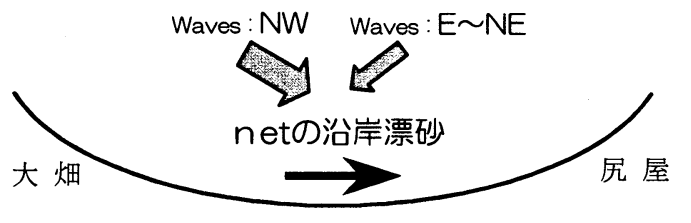

図-3下北半島の津軽海峡沿岸における漂砂機構

\section{(2) 今後の方策}

石持漁港以東の沿岸海域ではホタテ養殖が行われ ているが, 海食崖の崩落に伴って発生する濁りが漁 業生産の低下を招いている.その意味では海食崖の 崩落防止は国土保全上からだけではなく,沿岸の漁 場保全においても必要とされているが,現在の所そ れらを総合的に考えた対策は進められていない。

侵食の激しい浜関根港や石持漁港の東側に連なる 海食崖の基部に消波堤を設置するか, あるいは海食 崖の沖合に連続的に離岸堤を建設すれば侵食防護は 可能であるが, それには膨大な投資を必要とし，しか も大部分の地域の土地利用が原野であることから投 資効果が問題とされよう.

以上の制約条件の中で現実的対応について考えて みる. 浜関根港の東側地区では既に長大な連続離岸 堤が設置されてきている.しかし一部開口幅の広い 場所,および離岸堤群の東端部で侵食が激しい.すで に大部分の区域に離岸堤が設置されていることを考
慮すれば,今から離岸堤以外の策に変更することは 難しいので, 開口幅が広い場所においては開口幅を 狭める策が現実的であろう.一方離岸堤群の東端以 東については, どこまでも離岸堤を造るという方式 はコスト面から考えて非現実的である.それよりも 石持漁港の防波堤がヘッドランド効果 ${ }^{2}$ を発揮して いることと,わずかながら汐崎も同様な効果を発揮 しているという事実を十分理解し，それらの存在に よって前浜が確保されている地点（写真一の点C） までを対象区域として,そこにへッドランドないし は離岸堤を建設することにより上手（西）側に安定 な前浜を形成させ,そこより東側は砂浜自体を海食 崖の有効な消波施設として位置付けることが必要で ある。

石持漁港から野牛漁港の間では前浜はほとんど消 失しているか, あるいは非常に狭く, 海食崖の侵食防 止効果は期待できない.この区域の海食崖の崩落か ら発生する濁りがホタテ養殖の障害となっているこ とは前述の通りである.波食による海食崖の後退を 止めるには波の作用を弱めることが必要であり,そ れには(1)養浜によって砂浜を回復させる,(2)海食崖 の基部に消波堤を並べる,(3)離岸堤を設置する方法 などが考えられる.しかし，例えば離岸堤を設置すれ ば,それが設置されたことから東側端部で新たに侵 食が発生し,さらに設置区域が延びるという問題点 があることに注意が必要であって,これらの投資が 国土保全と沿岸漁場保全にもたらす効果と見合うか どうかについての検討が必要であり,場合によって は現況のまま放置するという考え方もあろう.

\section{5.あとがき}

津軽海峡沿岸の大畑〜尻屋崎の海岸線は, 大都市 近郊の海岸線と比較して開発の進みは遅い. それで もこの沿岸にはいくつかの港湾や漁港が立地してい る.しかしながらそれらの施設の周辺では沿岸漂砂 にアンバランスが生じ,海食崖の形成を伴って侵食 が進んでいることが明らかになった.大都市近郊の 海岸であれば侵食が多くの人々の目に触れ, 早期に その対策も議論されるのであるが，この沿岸ではそ の機会は稀である.すでに人為的地形改変が加えら れている以上,自然現象としての侵食は今後も着実 に進むので,海食崖の後退にとどまらず,沿岸域の漁 場環境の保全においても危惧される状況となる可能 性が高い.このことからより詳細な調查を行い,事態 がより深刻化する前に必要な策を考えることが必要 である.

\section{参考文献}

1) 宇多高明(1997):日本の海岸侵食,山海堂,p.442.

2) 渡辺宗介・清野聡子 - 宇多高明 - 芹沢真澄 - 三波 俊郎 - 古池 鋼(2000): 青森県三沢漁港周辺の海浜 変形と今後の海岸保全,海洋開発論文集,第 16 巻,pp.607-612. 